\title{
KONSEP DASAR EVALUASI DALAM PEMBELAJARAN MATEMATIKA
}

\section{oleh}

\section{Ismawati Haris}

\section{ismawatiharis26@gmail.com}

\begin{abstract}
Abstrak
Evaluasi merupakan salah satu cara dalam mengetahui hasil belajar yang telah dicapai oleh peserta didik selama proses pembelajaran. Pendidik dapat melakukan evaluasi berupa evaluasi hasil belajar dan evaluasi pembelajaran. Evaluasi pembelajaran merupakan salah satu kompetensi profesional seorang pendidik dalam meningkatkan mutu pembelajaran. Penilaian adalah sebuah proses untuk menentukan nilai belajar dan pembelajaran yang dilaksanakan. Pengukuran adalah tindakan atau proses untuk menentukan kuantitas sesuatu, karena itu biasanya diperlukan alat bantu. Tes merupakan salah satu cara untuk menaksir besarnya kemampuan peserta didik, biasanya dilakukan secara langsung. sehingga alat ukur yang sering digunakan dalam evaluasi pembelajaran adalah tes.
\end{abstract}

\section{A. Latar Belakang}

Matematika merupakan salah satu mata pelajaran wajib pada jenjang sekolah dasar, sekolah menengah pertama dan sekolah menengah atas. Pembelajaran matematika membutuhkan interaksi antara guru dan siswa serta antarsiswa(Irmayanti et al., 2020). Matematika adalah ilmu yang memiliki peran penting dalam penggunaannya atau aplikasi di kehidupan sehari-hari. Sehingga hal ini menjadi salah satu pertimbangan dalam pelaksanaan pembelajaran yang mampu memberikan pemahaman pada siswa(Rahayu et al., 2020).

Seperti yang telah diketahui pula bahwa dalam matematika objek yang dipelajari merupakan objek yang bersifat abstrak, seperti operasi, konsep, maupun prinsipnya. Sehingga, menumbuhkan keterampilan atau kemampuan berpikir kritis siswa sangat diperlukan dalam mata pelajaran matematika, agar penguasaan suatu konsep tidak hanya berupa hafalan dari sejumlah konsep yang telah dipelajarinya(Nurhikmah \& 
Ernawati, 2020). Proses pendidikan, kegiatan belajar dan pembelajaran merupakan suatu usaha yang amat strategis untuk mencapai tujuan yang diharapkan(Satriyawan \& Lusyana, 2020).

Mutu pendidikan dipengaruhi banyak faktor, diantaranya adalah siswa, pengelola sekolah, lingkungan, kualitas pembelajaran, dan kurikulum. Usaha peningkatan kualitas pendidikan dapat ditempuh melalui peningkatan kualitas pembelajaran dan kualitas sistem penilaian. Keduanya saling berkaitan karena sistem pembelajaran yang baik akan menghasilkan kualitas belajar yang baik. Selanjutnya sistem penilaian yang baik akan mendorong guru untuk menentukan strategi mengajar yang baik serta memotivasi siswa untuk belajar yang lebih baik.

Salah satu faktor yang penting untuk mencapai tujuan pendidikan dengan demikian adalah proses pembelajaran yang dilakukan, sedangkan salah satu faktor penting untuk keefektifan pembelajaran adalah faktor evaluasi, baik terhadap program, proses, maupun hasil pembelajaran. Hal yang paling penting dalam pembelajaran yang harus diperhatikan adalah proses, bukan semata-mata hasil akhir(Nurjannah et al., 2020). Namun, evaluasi dapat mendorong guru untuk meningkatkan kualitas proses pembelajaran serta mendorong sekolah untuk meningkatkan fasilitas dan kualitas manajemen sekolah(Gunawan, 2003).

Pada dasarnya pendidik atau calon pendidik harus bisa mengajar, tetapi juga harus mempunyai kemampuan melakukan kegiatan evaluasi dengan tepat. Sebelum melakukan penilaian pembelajaran, pendidik atau calon pendidik harus memahami arti evaluasi pembelajaran, tujuan, fungsi, dan ruang lingkup dan model evaluasi pembelajaran. Oleh karena itu, dalam makalah ini penulis akan menjelaskan mengenai konsep dasar evaluasi pembelajaran, karena bagi pendidik maupun yang diorientasikan menjadi seorang pendidik hal ini sangatlah penting.

\section{B. Rumusan Masalah}

1. Bagaimanakah konsep dasar evaluasi?

2. Apakah defenisi evaluasi, penilaian, pengukuran dan test?

3. Apakah tujuan dan fungsi evaluasi pembelajaran?

4. Bagaimanakah ruang lingkup evaluasi pembelajaran? 
5. Bagaimanakah model-model evaluasi pembelajaran?

\section{Tujuan Penulisan Makalah}

Tujuan penulisan makalah ini untuk memenuhi salah satu tugas mata kuliah Metodologi Penelitian Pendidikan Matematika. Selain itu, penulisan makalah ini juga bertujuan untuk mengetahui dan memahami tentang pengertian, tujuan, fungsi, ruang lingkup dan model-model pembelajaran. 


\section{A. Konsep Dasar Evaluasi Pembelajaran}

Undang-Undang Nomor 20 Tahun 2003 pasal 39 ayat 2 tentang Sistem Pendidikan Nasional menyatakan bahwa pendidik adalah tenaga professional yang bertugas merencanakan dan melaksanakan proses pembelajaran, menilai hasil pembelajaran, melakukan bimbingan dan pelatihan, serta melakukan penelitian dan pengabdian kepada masyarakat, terutama bagi pendidik pada perguruan tinggi. Dengan demikian, salah satu kompetensi yang harus dimiliki seorang pendidik adalah kemampuan mengadakan evaluasi, baik dalam proses pembelajaran maupun penilaian hasil belajar. Kemampuan melaksanakan evaluasi pembelajaran merupakan kemampuan dasar yang mesti dikuasai oleh seorang pendidik maupun calon pendidik sebagai salah satu kompetensi professionalnya. Kompetensi profesional seorang pendidik salah satu indikatornya adalah melakukan evaluasi pembelajaran. Dimana, kompetensi tersebut sejalan dengan instrumen penilaian kemampuan guru.

\section{B. Pengertian Evaluasi, Penilaian, Pengukuran dan Test}

Istilah penilaian pembelajaran biasanya setara dengan pengujian. Meskipun terkait satu sama lain, namun tidak mencakup semua arti yang sebenarnya. Ujian ulangan harian yang dilakukan oleh guru di dalam kelas, bahkan ujian akhir pun tidak dapat menggambarkan sifat penilaian pembelajaran, apalagi jika dikaitkan dengan penerapan kurikulum 2013, karena penilaian pembelajaran pada dasarnya bukan hanya sekedar penilaian terhadap hasil belajar. Dan proses yang dialami oleh pendidik dan peserta didik sepanjang proses pembelajaran.

Wrightstone, dkk. (Djaali \& Pudji Muljono, 2007). yang mengemukakan bahwa evaluasi pendidikan adalah penaksiran terhadap pertumbuhan dan kemajuan siswa kearah tujuan atau nilai-nilai yang telah ditetapkan oleh kurikulum. lebih spesifik Grondlund dan Linn (1990), mendefinisikan evaluasi pembelajran adalah suatu proses mengumpulkan, menganalisis dan menginterpretasi informasi secaras sistematik untuk menetapkan sejauh mana ketercapaian tujuan pembelajaran.(Magdalena et al., 2020) 
Worthen dan Sanders (1973, dalam Suharsimi Arikunto 2010:1), mengatakan bahwa evaluasi adalah kegiatan mencari sesuatu yang berharga tentang sesuatu dalam mencari sesuatu tersebut, juga mencari informasi yang bermanfaat dalam menilai keberadaan suatu program, produksi, prosedur serta alternatif strategi yang diajukan untuk mencapai tujuan yang sudah di tentukan.(Rahmawati, 2010)

Pengertian evaluasi secara umum dapat diartikan sebagai proses sistematis untuk menentukan nilai sesuatu (ketentuan, kegiatan, keputusan, unjuk-kerja, proses, orang, objek dan yang lainnya) berdasarkan kriteria tertentu melalui penilaian. Untuk menentukan nilai sesuatu dengan cara membandingkan dengan kriteria, evaluator dapat langsung membandingkan dengan kriteria umum, dapat pula melakukan pengukuran terhadap sesuatu yang dievaluasi kemudian membandingkan dengan kriteria tertentu. Dalam pengertian lain antara evaluasi, pengukuran, dan penilaian merupakan kegiatan yang bersifat hirarki. Artinya ketiga kegiatan tersebut dalam kaitannya dengan proses pembelajaran tidak dapat dipisahkan satu sama lain dan dalam pelaksanaannya harus dilaksanakan secara berurutan. Dalam kaitan ini ada dua istilah yang hamper sama tetapi sesungguhnya berbeda, yaitu penilaian dan pengukuran. Pengertian pengukuran terarah kepada tindakan atau proses untuk menentukan kuantitas sesuatu, karena itu biasanya diperlukan alat bantu. Sedangkan penilaian atau evaluasi terarah pada penentuan kualitas atau nilai sesuatu. Evaluasi belajar dan pembelajaran adalah proses untuk menentukan nilai belajar dan pembelajaran yang dilaksanakan, dengan melalui kegiatan penilaian atau pengukuran belajar dan pembelajaran. Sedangkan pengertian pengukuran dalam kegiatan pembelajaran adalah proses membandingkan tingkat keberhasilan belajar dan pernbelajaran dengan ukuran keberhasilan belajar dan pembelajaran yang telah ditentukan secara kuantitatif sementar pengertian penilaian belajar dan pembelajaran adalah proses pembuatan keputusan nilai keberhasilan belajar dan pembelajaran secara kualitatif.(Mahirah, 2017)

Tes merupakan salah satu cara untuk menaksir besarnya kemampuan seseorang secara tidak langsung, yaitu melalui respons seseorang terhadap stimulus atau pertanyaan (Mardapi, 1999:2). Tes merupakan salah satu alat untuk melakukan pengukuran, yaitu alat untuk mengumpulkan informasi karakteristik suatu obyek. Obyek ini bisa berupa kemampuan siswa, sikap, minat, maupun motivasi. Respons 
peserta tes terhadap sejumlah pertanyaan menggambarkan kemampuan dalam bidang tertentu. Tes merupakan bagian tersempit dari evaluasi(Gunawan, 2003).

\section{Ruang Lingkup Evaluasi Pembelajaran}

Berbicara tentang ruang lingkup evaluasi pembelajaran, maka perlu dibedakan antara penilaian dan evaluasi dalam konteks ruang lingkup ini. Dalam konteks pembelajaran, lingkup atau cakupan penilaian hanya pada individu siswa dalam kelas, sedangkan lingkup evaluasi adalah seluruh komponen dalam program pembelajaran, mulai dari input, proses, sampai pada hasil pembelajaran. Dalam proses pembelajaran, cakupan evaluasi meliputi siswa, guru, kurikulum, sarana dan prasarana atau media pembelajaran, iklim kelas, sikap siswa dalam pembelajaran, dan sebagainya. Dengan demikian perbedaan prinsip antara penilaian dengan evaluasi adalah pada cakupan. Penilaian mencakup satu aspek, sedangkan evaluasi mencakup beberapa aspek dalam program. Kegiatan evaluasi selalu terkait dengan program.(Haryanto, 2020)

Karena aspek penilaian ini begitu luas, tentu jadinya Ruang lingkup ini tidak akan membahas luasnya semua aspek Evaluasi. Namun, yang ingin Anda evaluasi dalam buku ini adalah Evaluasi pembelajaran atau hasil belajar saja. Evaluasi pembelajaran ini Itu sendiri termasuk belajar mengajar itu sendiri, jadi Pada dasarnya review buku ini coba dibahas Penilaian berkaitan dengan mata pelajaran dan objek pembelajaran itu sendiri, Artinya, guru dan siswa.

Dalam kaitan dengan pencapaian akademik, itu berarti ruang lingkup evaluasi pembelajaran lebih pada sistem pembelajarannya. Dalam hal ini, ada dua bagian besar, yaitu program pembelajaran itu sendiri dan juga proses pelaksanaan pembelajarannya.(Haryanto, 2020) Untuk program pembelajaran meliputi:

1. tujuan pembelajaran umum atau kompetensi dasar, yaitu target yang harus dikuasai peserta didik dalam setiap pokok bahasan topik. Kriteria yang digunakan untuk mengevaluasi tujuan pembelajaran umum atau kompetensi dasar ini adalah keterkaitannya dengan tujuan kurikuler atau standar kompetensi dari setiap bidang studi dan tujuan kelembagaan, kejelasan rumusan kompetensi dasar, kesesuaiannya dengan tingkat perkembangan anak didik, pengembangannya dalam bentuk hasil belajar dan indikator, penggunaan kata kerja operasional dalam indikator, dan unsur-unsur penting dalam kompetensi dasar, hasil belajar, dan indikator. 
2. Isi atau materi pembelajaran, yaitu isi kurikulum berupa topik pokok bahasan dan subtopik/subpokok bahasan beserta perinciannya dalam setiap bidang studi atau mata pelajaran. Isi kurikulum sendiri terdiri atas tiga, yaitu: logika, etika, dan estetika. Sedangkan materi pembelajaran dapat dikelompokkan menjadi enam jenis, yaitu fakta, konsep/teori, prinsip, proses, nilai, dan keterampilan. Kriteria yang digunakan adalah kesesuaiannya dengan kompetensi dasar dan hasil belajar, ruang lingkup materi, urutan logis materi, kesesuaiannya dengan tingkat perkembangan dan kebutuhan peserta didik, waktu yang tersedia, dan sebagainya.

3. Metode pembelajaran, yaitu cara guru menyampaikan materi pelajaran. Kriteria yang digunakan adalah kesesuaiannya dengan kompetensi dasar dan hasil belajar, dengan kondisi kelas atau sekolah, dengan tingkat perkembangan anak didik, kemampuan guru dalam menggunakan metode, dan waktu yang tersedia.

4. Media pembelajaran, yaitu alat yang membantu untuk mempermudah guru menyampaikan materi pelajaran.

5. Sumber belajar, yaitu meliputi pesan, orang, bahan, alat, teknik, dan latar, baik dengan sumber belajar yang dirancang (by design) maupun sumber yang digunakan (by utilization).

6. Lingkungan, terutama lingkungan sekolah dan keluarga.

7. Penilaian proses dan hasil belajar, baik yang menggunakan tes maupun yang nontes.

Sedangkan untuk pelaksanaan program pembelajaran meliputi hal-hal sebagai berikut:

1. Kegiatan, yang meliputi jenis kegiatan, prosedur pelaksanaan setiap jenis kegiatan, sarana pendukung, efektivitas dan efisiensi, dan sebagainya.

2. Guru, terutama dalam hal menyampaikan materi, kesulitan guru, penciptaan suasana pembelajaran yang kondusif, kelengkapan alat bantu mengajar, penggunaan teknik penilaian, dan semacamnya.

3. Peserta didik, terutama dalam peran mereka dalam kegiatan belajar dan bimbingan, memahami jenis kegiatan, mengerjakan tugas-tugas, perhatian, keaktifan, motivasi, sikap, minat, umpan balik, dan semacamnya.

\section{E. Model-model Evaluasi Pembelajaran}

Pada dasarnya, ada dua mode evaluasi, yaitu: model evaluasi kuantitatif dan model evaluasi kualitatif. Pada dasarnya, model evaluasi kuantitatif muncul dari 
paradigma positivisme, lebih memfokuskan pada dimensi kurikulum sebagai hasil belajar, dan hasil belajarnya merupakan kriteria model kuantitatif. Sedangkan evaluasi kualitatif berasal dari model evaluasi kurikulum, menggunakan metodologi kualitatif pada saat pengumpulan data dan evaluasi, serta menggunakan model studi kasus dalam melakukan evaluasi.(Haryanto, 2020)

Menurut Said Hamid Hasan, model evaluasi kuantitatif terdiri dari banyak model, seperti model Tyler, model teoretik Taylor dan Maquire, model pendekatan sistem Alkin, model countenance Stake, model CIPP, dan model ekonomi mikro. Sedangkan model evaluasi kualitatif terdiri dari model studi kasus, model iluminatif, dan model responsif. Untuk memahami berbagai model tersebut, berikut ini adalah sebagian dari penjelasan terhadap model-model tersebut, baik model evaluasi kuantitatif maupun yang kualitatif.(Haryanto, 2020)

\section{Model Tyler}

Model Tyler adalah model yang pertama kali muncul dan digunakan dalam proses evaluasi. Model yang muncul pada 1949 itu bernama model black box, dan dipergunakan selama 10 tahun sebagai satu-satunya model evaluasi program yang digunakan dalam dunia pendidikan. Hal ini mungkin disebabkan karena evaluasi belum menjadi studi tersendiri, karena ketika itu orang banyak mempelajari evaluasi dari psikometrik dengan kajian utamanya adalah tes dan pengukuran. Evaluasi lebih banyak diarahkan kepada dimensi hasil, belum masuk ke dimensi-dimensi yang lain. Oleh sebab itu, jangan heran bila evaluasi banyak dilakukan oleh orang-orang yang "terbentuk" dalam tes dan pengukuran. Baru sekitar dasawarsa 1960an, studi evaluasi mulai berdiri sendiri dan menjadi salah satu program studi di perguruan tinggi.

Model Tyler atau model Black Box ini sangat menekankan adanya tes awal (pretest) dan tes akhir (post-test), sehingga proses diabaikan dalam hal ini, dan pengabaian terhadap proses inilah yang dimaksudkan sebagai kotak hitam (black box) yang menyimpan banyak teka-teki. Karena itulah, menurut Tyler, ada tiga langkah pokok yang harus dilakukan, yaitu menentukan tujuan pembelajaran yang akan dievaluasi, menentukan situasi di mana peserta didik memperoleh kesempatan untuk menunjukkan tingkah laku yang berhubungan dengan tujuan, dan menentukan alat evaluasi yang akan dipergunakan untuk mengukur tingkah laku peserta didik. 
Jadi, model ini menekankan adanya proses evaluasi secara langsung didasarkan atas tujuan instruksional yang telah ditetapkan bersamaan dengan persiapan mengajar, ketika seorang guru berinteraksi dengan para siswanya menjadi sasaran pokok dalam proses pembelajaran. Program pembelajaran dikatakan berhasil dalam pandangan model Tyler ini jika para siswa yang mengalami proses pembelajaran dapat mencapai tujuan yang telah ditetapkan dalam proses belajar-mengajar.

Model ini dibangun atas dasar dua dasar pemikiran. Pertama, evaluasi ditujukan pada tingkah laku anak didik. Kedua, evaluasi harus dilakukan pada tingkah laku awal peserta didik sebelum melaksanakan kegiatan pembelajaran dan sesudah melaksanakan kegiatan pembelajaran (hasil). Dasar pemikiran kedua ini menunjukkan bahwa seorang evaluator harus dapat menentukan perubahan tingkah laku apa yang terjadi setelah peserta didik mengikuti pengalaman belajar tertentu, dan menegaskan bahwa perubahan yang terjadi merupakan perubahan yang disebabkan oleh pembelajaran.

Dengan demikian, untuk bisa menunjukkan adanya perubahan tersebut, penentuan tujuan atau kriteria yang telah ditetapkan sebelumnya menjadi tolok ukur, dan hal inilah yang dijadikan sebagai pedoman untuk dievaluasi. Dalam hal ini, Tyler dalam Basic Principles of Curriculum and Instruction (1950) menyatakan bahwa proses evaluasi esensinya adalah suatu proses dan kegiatan yang dilakukan oleh seorang evaluator untuk menentukan pada kondisi apa tujuan tersebut bisa dicapai.

Dengan demikian, pada dasarnya model Tyler ini lebih menitikberatkan pada bagaimana tujuan itu bisa dicapai dengan melakukan tes awal dan tes akhir untuk bisa menentukan apakah hasil yang didapatkan oleh anak didik itu sudah sesuai dengan tujuan atau standar yang telah ditetapkan. Pendekatan ini pun menjadi pendekatan yang sistematis, elegan, akurat, dan secara internal memiliki rasionalisasi yang logis. Bahkan dalam implementasinya, model Tyler ini menggunakan unsur pengukuran dengan usaha secara konstan, paralel, dan dengan inquiry ilmiah dan melengkapi legitimasi untuk mengangkat pemahaman tentang evaluasi. Namun, Tyler membedakan antara evaluasi dengan pengukuran, yang mana menurutnya pengetahuan pengukuran dan pengetahuan evaluasi itu terpisah dan merupakan proses di mana pengukuran hanya satu dari beberapa kemungkinan salah satu cara dalam mendukung tercapainya evaluasi.

2. Model Berorientasikan Tujuan (Goal-Oriented Evaluation) 
Model ini biasa diterapkan dalam proses kurikulum di negeri ini, yang meliputi tujuan pembelajaran umum dan tujuan pembelajaran khusus. Kedua tujuan tersebut itulah yang dijadikan patokan tingkat keberhasilan pembelajaran dan dijadikan sebagai alat evaluasi untuk mengetahui kinerja pengajaran dan pembelajaran di dalam kelas. Dengan demikian, evaluasi dimaknai sebagai proses pengukuran untuk mengetahui sejauh mana tujuan pembelajaran itu tercapai. Karena itulah model ini sangatlah praktis mengingat hasil yang diinginkan bisa ditentukan melalui pengukuran yang sudah terumuskan sebelumnya.

Dengan demikian, model berorientasikan tujuan ini menghubungkan secara logis tiga rangkaian, yaitu kegiatan, hasil, dan prosedur pengukuran hasil. Tujuannya adalah untuk membantu guru merumuskan tujuan dan menjelaskan hubungan antara tujuan dengan kegiatan. Jika rumusan tujuan pembelajaran dapat diamati dan dapat diukur, maka kegiatan evaluasi pembelajaran akan menjadi lebih praktis dan sederhana. Di samping itu, model ini dapat membantu guru menjelaskan rencana pelaksanaan kegiatan pembelajaran dengan proses pencapaian tujuan. Instrumen yang digunakan bergantung pada tujuan yang ingin diukur. Hasil evaluasi akan menggambarkan tingkat keberhasilan tujuan program pembelajaran berdasarkan kriteria program khusus. Kelebihan program ini terletak pada hubungan antara tujuan dan kegiatan serta menekankan pada anak didik sebagai aspek penting dalam proses pembelajaran. Namun kekurangannya adalah memungkinkan terjadinya proses evaluasi melebihi konsekuensi yang tidak diharapkan.

\section{Model Evaluasi Sistem}

Model ini bertitik tolak dari pandangan bahwa keberhasilan dari suatu sistem pendidikan dipengaruhi oleh beragam faktor, karakteristik anak didik maupun lingkungan di sekitarnya, tujuan sistem dan peralatan yang dipakai, serta prosedur dan mekanisme pelaksanaan sistem itu sendiri.

Ada beberapa hal penting dari model evaluasi sistem ini, yaitu sebagai berikut:

1) Model ini menekankan pentingnya sistem sebagai suatu keseluruhan yang dijadikan sebagai objek evaluasi tanpa membatasi pada aspek hasil yang dicapai saja.

2) Perbandingan antara kinerja dengan kriteria merupakan salah satu inti penting dalam konsep evaluasi sistem ini. Karena itulah, untuk setiap dimensi sistem 
pendidikan yang dikembangkan perlu ditetapkan dengan tegas kriteria yang dijadikan ukuran dalam mengevaluasi kinerja dari masing-masing dimensi tersebut.

3) Kegiatan evaluasi tidak hanya berakhir pada suatu deskripsi tentang keadaan sistem yang dinilai, melainkan harus sampai pada suatu keputusan mengenai baik buruknya dan efektif tidaknya sistem pembelajaran atau pendidikan yang bersangkutan.

Dalam pandangan model sistem ini, evaluasi berarti membandingkan performance (kinerja) dari berbagai dimensi (tidak hanya dimensi hasil saja) dengan sejumlah criterion/kriteria, baik yang bersifat mutlak/intern maupun bersifat relatif/ekstern). Model ini menekankan pada sistem sebagai suatu keseluruhan dan merupakan penggabungan dari berbagai model, sehingga objek evaluasinya dapat diambil dari beberapa model evaluasi.

4. Model Alkin

Model Alkin ini dinisbahkan kepada nama pencetusnya yaitu Marvin Alkin. Menurutnya, evaluasi adalah proses untuk meyakinkan keputusan, mengumpulkan informasi, memilih informasi yang tepat, dan menganalisis informasi sehingga dapat disusun laporan bagi pembuat keputusan dalam memilih beberapa alternatif.

Ada beberapa jenis evaluasi dalam model Alkin, yaitu sebagai berikut: pertama, penilaian sistem, yaitu untuk memberikan informasi tentang keadaan atau posisi dari suatu sistem. Kedua, perencanaan program, yaitu untuk membantu pemilihan program tertentu yang mungkin akan berhasil memenuhi kebutuhan program. Ketiga, implementasi program, yaitu untuk menyiapkan informasi apakah suatu program sudah diperkenalkan kepada kelompok tertentu yang tepat sebagaimana yang direncanakan atau tidak. Keempat, perbaikan program, yaitu memberikan informasi tentang bagaimana suatu program dapat berfungsi, bekerja atau berjalan. Kelima, sertifikasi program, yaitu memberikan informasi tentang nilai atau manfaat dari suatu program.

5. Model Michael Scriven (Evaluasi Sumatif-Formatif)

Model evaluasi Scriven ini sudah banyak dikenal oleh umum dari segi fungsinya, dan evaluasi ini terbagi ke dalam dua bentuk, yaitu formatif dan sumatif. Karena itulah, model ini lebih dikenal sebagai model sumatif dan formatif, dan Scriven adalah orang yang mempopulerkan model tersebut. 
Dalam hal ini, model ini sudah banyak dipahami oleh para guru, karena model ini dianjurkan oleh pemerintah dan termasuk dalam lingkup evaluasi pembelajaran di kelas.

Evaluasi formatif berfungsi untuk memperbaiki kurikulum dan pembelajaran, sedangkan evaluasi sumatif berfungsi untuk melihat kebermanfaatan kurikulum dan pembelajaran secara menyeluruh. Dengan demikian, jika hasil kurikulum dan pembelajaran memang bermanfaat bagi semua pihak yang terkait (terutama peserta didik), maka kurikulum dan pembelajaran tersebut dapat dilanjutkan. Sebaliknya, jika hasil kurikulum dan pembelajaran tidak mempunyai manfaat, maka kurikulum dan pembelajaran tersebut dapat dihentikan.

Sedangkan menurut Suharsimi Arikunto, evaluasi formatif berfungsi untuk mengumpulkan data selama kegiatan masih berlangsung. Data yang diperoleh dapat juga digunakan oleh pengembang program untuk membentuk dan mengadakan modifikasi terhadap program. Dalam beberapa hal, penemuan-penemuan dari penilaian dapat digunakan sebagai acuan bagi pelaksana untuk melaksanakan program selanjutnya agar tidak terjadi pemborosan.

Sedangkan evaluasi sumatif berfungsi untuk mengumpulkan data ketika kegiatan program betul-betul selesai. Evaluasi sumatif dilaksanakan untuk mengetahui kemanfaatan program, terutama jika dibandingkan dengan program lain. Data yang diperoleh dari evaluasi sumatif sangat berguna bagi pengambil keputusan dalam menentukan tindak lanjut.

Dengan demikian, evaluasi formatif adalah bagian dari proses pengajaran. Ketika digabungkan dalam praktik dalam kelas, evaluasi formatif memberikan informasi yang dibutuhkan untuk menyesuaikan pengajaran dan pembelajaran ketika proses tersebut terjadi. Dalam pemahaman ini, evaluasi formatif menginformasikan baik kepada guru maupun siswa tentang pemahaman anak didik pada satu titik ketika penyesuaian-penyesuaian bisa dibuat pada waktunya. Berbagai penyesuaian ini membantu menjamin pencapaian anak didik, yang menargetkan berbagai tujuan pembelajaran berbasiskan standar dalam seperangkat waktu.

6. Model Robert Glaser

Model ini dikembangkan oleh Glaser yang mana dia berupaya untuk memberikan detail yang lebih baik tentang evaluasi dalam proses pembelajaran dan 
pengajaran. Menurutnya, ada enam langkah yang bisa dilalui dalam proses evaluasi pembelajaran dan pengajaran, yaitu sebagai berikut:

a. Mengidentifikasi hasil belajar. Dalam hal ini, Glaser menyarankan agar tujuan kegiatan hendaknya dirumuskan dalam bentuk tingkah laku yang menunjukkan keterampilan yang harus diperoleh oleh siswa. Keterampilan tersebut kemudian harus disebutkan juga ukuran keberhasilannya secara eksplisit dan spesifik sesuai dengan yang diperlukan oleh kurikulum.

b. Mendiagnosis kemampuan awal (entry behavior). Dalam hal ini, Glaser menyatakan bahwa guru harus mengetahui terlebih dahulu kemampuan awal yang dimiliki oleh siswanya. Hal ini tentu saja berbeda dengan kemampuan dasar (bakat). Kemampuan awal menunjuk pada kemampuan prasyarat yang diperlukan sebagai dasar bagi pengetahuan atau keteramnpilan yang akan dipelajari. Sifatnya lebih menjurus pada aspek tertentu, sedangkan kemampuan dasar bersifat lebih umum.

c. Menyiapkan alternatif pengajaran. Hal ini tentu dilakukan dengan melihat kapasitas dan kapabilitas siswa, yakni dalam wujud kecepatan dalam belajar, latar belakang keluarga, latar belakang pengalaman, kebutuhan, serta gaya belajar dan kebiasaan lainnya.

d. Mengadakan pengawasan terhadap penampilan siswa. Jika suatu bentuk pengajaran telah dilaksanakan, perlu setelah itu harus diadakan pengawasan terhadap aplikasi bentuk pengajaran tersebut.

e. Menilai ulang alternatif pengajaran. Dalam hal ini, sebuah model pengajaran dan pembelajaran harus dievaluasi kefektifannya dalam proses kemajuan siswa. Penilaian ini didasarkan atas data umpak balik dari kegiatan pengamatan Glasser menekankan satu butir penting, yaitu dirumuskan dan dipatuhinya kriteria.

f. Menilai dan mengembangkan pengajaran. Glaser dalam hal ini berharap bahwa evaluasi formatif atau evaluasi mengumpulkan umpan balik bisa dilakukan agar pelaksanaan program pembelajaran bisa berjalan dengan baik.

Dengan langkah-langkah di atas, itu berarti Glaser lebih memerhatikan detaildetail dan proses-proses evaluasi terhadap perkembangan belajar anak dengan memberikan berbagai jalan alternatif pengajaran sehingga evaluasi akan menggambarkan tingkat kinerja dari sistem pengajaran tersebut yang diukur dari hasil 
belajar yang telah teridentifikasi sebelumnya. Pada akhirnya, dari hasil yang telah teridentifikasi dan terevaluasi tersebut, Glaser berupaya untuk mengembangkan pola pengajaran yang akan diterapkan pada saat pembelajaran.

\section{Model Iluminatif}

Model Iluminatif dikembangkan di Inggris dan banyak dikaitkan dengan pendekatan dalam bidang antropologi. Model ini merupakan salah satu bentuk model evaluasi kualitatif dan terbuka. Salah satu tokohnya yang paling menonjol adalah Malcolm Parlett.

Dalam hal ini, kegiatan evaluasi dihubungkan dengan lingkungan pembelajaran (learning milieu), dalam konteks sekolah sebagai lingkungan material dan psikososial, di mana guru dan anak didik dapat berinteraksi.

Tujuan evaluasi dalam model ini adalah untuk mempelajari secara cermat dan hati-hati terhadap pelaksanaan sistem pembelajaran, faktor-faktor yang memengaruhinya, kelebihan dan kekurangan sistem, dan pengaruh sistem terhadap pengalaman belajar anak didik. Dengan demikian, hasil evaluasi ini bersifat deskriptif dan penuh dengan penafsiran, sehingga bukan dalam bentuk pengukuran dan prediksi. Model ini lebih banyak menggunakan pertimbangan (judgement) yang berfungsi sebagai input untuk kepentingan pengambilan keputusan dalam rangka penyesuaian dan penyempurnaan sistem pembelajaran yang sedang dikembangkan.

\section{Model Responsif}

Model responsif ini sama dengan model iluminatif, yakni menekankan pada pendekatan kualitatif-naturalistik. Dengan kata lain, evaluasi tidak dimaknai sebagai sesuatu yang bisa diukur secara pasti, tapi dinilai dengan menggunakan makna atau gambaran dari sebuah realitas dengan menggunakan perspektif yang berbeda dari orangorang yang terlibat, berminat, dan berkepentingan dengan proses pembelajaran. Tujuan evaluasi dengan menggunakan model responsif ini adalah untuk memahami semua komponen program pembelajaran melalui berbagai sudut pandang yang berbeda. Sesuai dengan pendekatan yang digunakan, model ini kurang percaya terhadap hal-hal yang bersifat kuantitatif. Instrumen yang digunakan pada umumnya mengandalkan observasi langsung maupun tidak langsung dengan interpretasi data yang impresionistik. Langkah-langkah kegiatan evaluasi meliputi observasi, merekam hasil wawancara, mengumpulkan data, mengecek pengetahuan awal (preliminary understanding) peserta 
didik dan mengembangkan desain atau model. Berdasarkan langkah-langkah ini, evaluator mencoba responsif terhadap orang-orang yang berkepentingan pada hasil evaluasi. Sedangkan hal yang penting dalam model responsif adalah pengumpulan dan sintesis data.

Dalam berbagai model yang dijelaskan di atas, pada dasarnya Model sangat membantu untuk memahami struktur atau Suatu proses yang dapat digunakan para ahli saat mempelajari fenomena Penjelasan. Model di atas muncul karena mencoba menjelaskan Pembangunan berkelanjutan atas dasar pengembangan berkelanjutan Manusia sangat ingin mencoba menerapkan prinsip evaluasi Ruang lingkup yang lebih abstrak.

Namun dalam penerapan model evaluasi terdapat tiga hal terpenting Pembelajaran seperti ini dapat digunakan dengan sukses. Satu, perhatikan Tujuan pembelajaran adalah tujuan dan sasaran pembelajaran umum Pembelajaran khusus. Keduanya harus seimbang dan konsisten, tidak Sebaliknya, karena akan membuat tujuan besar melenceng dari tujuan yang diinginkan Dalam satu kursus. Kedua, pertimbangkan sistem sekolah Penting untuk mempertimbangkan sistem sekolah dengan cermat Sangat rumit karena harus mengandung berbagai komponen yang saling eksklusif Interaksi dan ketergantungan. Ketiga, bimbingan guru. Banyak program Pembinaan oleh guru yang tidak secara langsung mempengaruhi penilaian. Program Konseling Guru lebih menitikberatkan pada pengembangan Kursus dan metode pembelajaran. Hal ini pula yang menyebabkan perbaikan sistem evaluasi pembelajaran menjadi kurang efektif. Di samping itu, guru juga sering dihadapkan dengan beragam kegiatan, seperti membuat persiapan mengajar, mengikuti kegiatan ekstrakurikuler, penyesuaian diri, dan kegiatan administratif lainnya. Karena itulah, ketiga hal tersebut harus mendapat perhatian yang serius agar evaluasi pembelajaran menjadi lebih maksimal dan efektif dalam penerapannya. 


\section{A. Kesimpulan}

Evaluasi merupakan salah satu cara dalam mengetahui hasil belajar yang telah dicapai oleh peserta didik selama proses pembelajaran. Pendidik dapat melakukan evaluasi berupa evaluasi hasil belajar dan evaluasi pembelajaran. Evaluasi pembelajaran merupakan salah satu kompetensi profesional seorang pendidik dalam meningkatkan mutu pembelajaran. Penilaian adalah sebuah proses untuk menentukan nilai belajar dan pembelajaran yang dilaksanakan. Pengukuran adalah tindakan atau proses untuk menentukan kuantitas sesuatu, karena itu biasanya diperlukan alat bantu. Tes merupakan salah satu cara untuk menaksir besarnya kemampuan peserta didik, biasanya dilakukan secara langsung. sehingga alat ukur yang sering digunakan dalam evaluasi pembelajaran adalah tes.

Secara umum tujuan evaluasi pembelajaran adalah untuk mengetahui keefektifan dan efisiensi sistem pembelajaran secara luas.

Ruang lingkup evaluasi pembelajaran lebih pada sistem pembelajarannya. Dalam hal ini, ada dua bagian besar, yaitu program pembelajaran itu sendiri dan juga proses pelaksanaan pembelajarannya.

Menurut Said Hamid Hasan, model evaluasi kuantitatif terdiri dari banyak model, seperti model Tyler, model teoretik Taylor dan Maquire, model pendekatan sistem Alkin, model countenance Stake, model CIPP, dan model ekonomi mikro. Sedangkan model evaluasi kualitatif terdiri dari model studi kasus, model iluminatif, dan model responsif.

\section{B. Saran}

Dari pembahasan diatas, menunjukan bahwa seorang pendidik sangat memerlukan pemahaman tentang konsep dasar evaluasi demi tercapainya tujuan pembelajaran yang baik. selain itu, hendaknya makalah ini dapat menjadi referensi untuk pembuatan makalah sejenisnya. 


\section{DAFTAR PUSTAKA}

Gunawan, I. (2003). EVALUASI PROGRAM PEMBELAJARAN. 1, 1-13. http://ejournal.unipma.ac.id/index.php/JP/article/download/108/96

Haryanto. (2020). Evaluasi pembelajaran; Konsep dan Manajemen. In UNY Press. http://staffnew.uny.ac.id/upload/131656343/penelitian/EVALUASI PEMBELAJARAN.pdf

Irmayanti, I, Islamiah, I, \& Syarifuddin, S. (2020). Analisis sosiomatematika berbasis kearifan lokal dalam pembelajaran pada siswa sdn 224 palae. 1(2), 27-34. http://journal.iaimsinjai.ac.id/index.php/Jtm

Magdalena, I., Mulyani, F., Fitriyani, N., \& Hapsa Delvia, A. (2020). Konsep Dasar Evaluasi Pembelajaran Sekolah Dasar di SD Negeri Bencongan 1. Pensa, 2(April), 87-98. https://ejournal.stitpn.ac.id/index.php/pensa/article/download/818/562

Mahirah. (2017). Evaluasi Belajar Peserta Didik (Siswa). Idaarah: Jurnal Manajemen Pendidikan, 1(2), 257-267. https://doi.org/10.24252/idaarah.v1i2.4269

Nurhikmah, \& Ernawati. (2020). Pengaruh model team assisted individualization (tai) terhadap kemampuan berpikir kritis matematis siswa berbasis media whatsapp. 1(2), 19-26. http://journal.iaimsinjai.ac.id/index.php/Jtm

Nurjannah, N, Mirna, M, Nurlili, N \& Imunandar, A. A. (2020). Analisis kesalahan siswa dalam memecahkan masalah pisa ditinjau dari gender. JTMT : Jurnal Tadris Matematika, 1(2), 1-8. Retrieved from http://journal.iaiamsinjai.ac.id/index.php/Jtm/article/view/466.

Rahayu, A., Ernawati, \& Rahim, R. A. (2020). Perbandingan hasil belajar matematika dengan menggunakan model number head together (nht) dan think pair share (tps) berbasis media whatsapp. 1(2), 12-18. http://journal.iaimsinjai.ac.id/index.php/Jtm

Rahmawati. (2010). Evaluasi Proses Pembelajaran Matematika Di Sekolah Dasar Fullday Darul Ilmi Surabaya. https://jurnalmahasiswa.unesa.ac.id/index.php/jmtp/article/view/7720

Satriyawan, A. N., \& Lusyana, E. (2020). Pembelajaran dengan teknik penguatan positif, negatif dan penghukuman pada peserta didik dalam keluarga di masa daring. JURNAL Pendidikan Dasar Dan Keguruan, 5(2), 37-49. : http://journal.iaimsinjai.ac.id/index.php/JPDK 